\title{
Pengaruh Tripolifosfat sebagai Agen Taut Silang pada Membran Kitosan Terhadap Karakter Fisikokimia dan Kemampuan Permeasi
}

\author{
Retno Ariadi Lusiana ${ }^{*}$, Ahmad Suseno ${ }^{1}$, Khabibi $^{1}$, Cahyaning Gesti Faradina ${ }^{1}$ \\ 1 Departemen Kimia, Fakultas Sains dan Matematika, Universitas Diponegoro \\ *Corresponding author: retno.lusiana@live.undip.ac.id
}

Received: 23 April 2021 / Accepted: 01 Mei 2021

Available online: 08 Mei 2021

\begin{abstract}
Abstrak
Penelitian tentang modifikasi membran kitosan dengan taut silang menggunakan tripolifosfat telah dilakukan. Penelitian ini bertujuan untuk memodifikasi kitosan dengan tripolifosfat dan mengkarakterisasi serta menguji permeabilitasnya. Pada penelitian ini dihasilkan larutan dope kitosan tertaut silang tripolifosfat (CSTPP) dengan tiga rasio kitosan:tripolifosfat yaitu 1:0,5; 1:1; dan 1:2. Melalui metode inversi fasa didapatkan lembaran membran yang dipergunakan dalam proses permeasi kreatinin. Berdasarkan hasil karakterisasi Hasil karakterisasi menunjukkan bahwa modifikasi kitosan oleh TPP berpengaruh pada sifat fisikokimia membran. Kenaikan konsentrasi TPP dalam membran berkorelasi dengan peningkatan hidrofilisitas, nilai serapan air, derajat pengembangan, porositas, kemampuan fluks dan kemampuan permeasi membran. Membran CSTPP2 dengan rasio mol 1:1 antara kitosan:TPP memiliki kemampuan permeasi terbaik.
\end{abstract}

Kata Kunci: taut silang; membran, CSTPP, permeasi

\section{Pendahuluan}

Membran merupakan lapisan tipis semipermeabel yang mampu melewatkan komponen tertentu dan menahan komponen lainnya secara selektif [1]. Material utama membran bisa berasal dari polimer alam dan sintetik. Polimer alam, memiliki keunggulan, seperti degradable, regeneratif, mudah dibuat, namun ketahanan termal dan kimia yang rendah membuat aplikasinya terbatas. Polimer alam yang banyak digunakan sebagai bahan baku membran adalah kitosan. Kitosan merupakan senyawa glukosida yang larut dalam asam encer, dalam proses inversi fasa sederhana dapat membentuk film tipis membran. Kitosan memiliki dua gugus fungsi reaktif $\left(-\mathrm{OH}, \quad-\mathrm{NH}_{2}\right)$ yang mudah dimodifikasi untuk membentuk senyawa sesuai dengan apilikasi yang diinginkan. Selain itu, modifikasi akan membuat kitosan memiliki sifat yang lebih baik bila diaplikasikan sebagai membran semipermeabel [2].

Modifikasi kitosan dapat dilakukan dengan berbagai metode dengan berbagai bahan tambahannya [3]. Modifikasi kitosan yang telah banyak dilakukan adalah dengan reaksi taut silang dengan agen taut silang natrium tripolifosfat (NaTPP). Modifikasi kitosan dengan natrium tripolifosfat (NaTPP), telah banyak dilakukan, salah satunya oleh Bhumkar dan Pokharkar [4] dalam proses rekayasa jaringan. Berdasarkan penelitian tersebut diungkapkan bahwa hubungan taut silang ionik kitosan-NaTPP dapat memfasilitasi pengikatan kitosan secara kinetk dengan medium berair dalam kondisi fisiologis. Sintesis menggunakan metode ionik gelation (ionotropic gelation), dimana terjadi interaksi antara muatan negatif agen taut silang (TPP) dengan muatan positif gugus amina pada molekul kitosan. Kelebihan metode ini adalah reaksinya yang sederhana dengan temperatur yang relatif rendah dan tidak perlu menggunakan pelarut organik.

Hejjaji dkk. [5] mensintesis kitosan tertaut silang TPP dengan metode gelasi ionitropik untuk mengatur ukuran partikel. Dikemukakan bahwa ukuran partikel yang dihasilkan dipengaruhi oleh $\mathrm{pH}$ larutan. Ukuran partikel terkecil didapatkan pada $\mathrm{pH} 3,8$, pada $\mathrm{pH}$ tersebut diketahui bahwa kekuatan ion pada permukaannya lebih kuat dibanding pada $\mathrm{pH}$ yang lebih basa. Hal ini dapat diartikan bahwa pada $\mathrm{pH}$ tersebut ion fosfat dari NaTPP lebih banyak yang tertaut silang dengan 
kitosan. Febriasari dkk. [6], mengemukakan masuknya TPP pada struktur kitosan membuat jejari pori meningkat, hidrofilisitas membran meningkat. Lusiana dan Pronotoningtyas [7] melaporkan bahwa taut silang TPP-kitosan berhasil meningkatkan hidrofilisitas, dan kemampuan permeasi terhadap urea. Namun, dalam penelitian tersebut, taut silang hanya dilakukan pada satu konsentrasi TPP, sehingga membuka kemungkinan untuk mempelajari pengaruh TPP pada konsentrasi yang berbeda. Penelitian ini bertujuan untuk mempelajari karakter fisikokimia dan kemampuan permeasi urea, kreatinin dan juga vitamin B12 dari membran CSTPP dengan tiga rasio TPP terhadap kitosan.

\section{Metode Penelitian}

\subsection{Alat dan Bahan}

Alat yang digunakan meliputi: seperangkat alat gelas, $\mathrm{pH}$ meter digital, magnetic bar, stirer, oven, cawan petri, viskometer ostwald, seperangkat alat dialisis dead-end, Perkin Elmer 96681 Frontier Fourier Transform Infrared (FTIR) spectrophotometer, Shimadzu UV-2450 Spektrofotometer UV-Vis, tensile strength analyzer.

Bahan yang digunakan meliputi: kitosan (BM $61.256 \mathrm{~g} / \mathrm{mol})$, asam asetat glasial p.a $(\mathrm{BM}=$ $131,11 \mathrm{~g} / \mathrm{mol})$ (Merck), akuades, $\mathrm{NaOH}(\mathrm{BM}=40$ $\mathrm{g} / \mathrm{mol})$ (Merck), NaTPP $(\mathrm{BM}=367,86 \mathrm{~g} / \mathrm{mol})$, kreatinin $(\mathrm{BM}=113,11 \mathrm{~g} / \mathrm{mol})($ Merck), urea $(\mathrm{BM}$ $=60 \mathrm{~g} / \mathrm{mol})($ Merck $)$, asam pikrat $(\mathrm{BM}=229,11$ $\mathrm{g} / \mathrm{mol})$ (Merck), $p$-dimetilamin benzaldehid ( $p$ DMAB BM $=149,19 \mathrm{~g} / \mathrm{mol})$, etanol $\mathrm{p}$ a $96 \%$ (Merck), $\mathrm{HCl} 37 \%$ (Merck), dan larutan penyangga (buffer phospat dan buffer phospat salin).

\subsection{Cara Kerja}

\subsubsection{Sintesis Kitosan Tertaut Silang Tripolifosfat}

Sebanyak 1,5 gram kitosan dilarutkan dalam $90 \mathrm{~mL}$ asam asetat $1 \%$. Selanjutnya ditambahkan $10 \mathrm{~mL}$ larutan NaTPP tetes demi tetes. Kondisi reaksi dipertahankan pada $\mathrm{pH} 3,8$ [5], dipanaskan pada suhu $55^{\circ} \mathrm{C}$ dan dilakukan selama 4 jam. Untuk menyempurnakan reaksi, larutan dope dimasukan dalam ultrasonifikator pada suhu $55^{\circ} \mathrm{C}$ selama 15 menit dan selanjutnya disimpan sebagai larutan stok membran. Perbandingan kitosan dan NaTPP pada sintesis membran terlihat pada Tabel $\mathbf{1}$.
Tabe1 1. Perbandingan kitosan dan NaTPP

\begin{tabular}{ccc}
\hline $\begin{array}{c}\text { Jenis } \\
\text { membran }\end{array}$ & $\begin{array}{c}\text { Kitosan } \\
\text { (g) }\end{array}$ & $\begin{array}{c}\text { NaTPP } \\
\text { (g) }\end{array}$ \\
\hline CS & 1,5 & 0 \\
CSTPP 1 & 1,5 & 1,7243 \\
CSTPP 2 & 1,5 & 3,4487 \\
CATPP 3 & 1,5 & 6,8974 \\
\hline
\end{tabular}

\subsubsection{Pembuatan Membran}

Sebanyak $5 \mathrm{~mL}$ larutan dope CSTPP dituangkan dalam cawan petri dan dikeringkan oven pada suhu $40-50^{\circ} \mathrm{C}$ selama 24 jam. Setelah kering ditambah larutan $\mathrm{NaOH}$ dan dicuci hingga netral.

\subsubsection{Karakterisasi Membran}

Karakterisasi pada membran meliputi identifikasi gugus fungsi (FTIR), hidrofilisitas, serapan air, derajat pengembangan, porositas, fluks air dan kuat tarik membran.

Pengukuran berat membran dilakukan dengan neraca analitik OHAUS dengan menimbang setiap sampel. Pengukuran tebal membran menggunakan alat thickness meter dengan pengulangan 5 kali pada titik yang berbeda secara acak dan dihitung rata-ratanya.

Uji hidrofilisitas. Membran diletakan pada papan datar dengan latar belakang hitam lalu diberi 1 tetes akuades tepat diatas permukaan sampel membran. Tetesan air pada permukaan membran diambil gambarnya dengan kamera kamudian dilihat sudut kontak dengan corel draw.

Uji serapan air. Sampel membran ditimbang berat awal, kemudian direndam dengan akuades $10 \mathrm{~mL}$ selama 6 jam. Setelah perendaman, membran ditimbang kembali. Berat awal dan berat setelah perendaman digunakan untuk menentukan persen serapan air membran.

Derajat pengembangan. Sampel membran diukur diameternya sebagai diameter awal. Kemudian membran direndam dengan akuades $10 \mathrm{~mL}$ selama 24 jam. Setelahnya, diukur diameter membran setelah perendaman. Diameter awal (Di) dan diameter membran setelah perendaman $(\mathrm{Dt})$ digunakan untuk menentukan derajat pengembangan membran.

Pengujian porositas membran diawali dengan perendaman membran dalam akuades $10 \mathrm{~mL}$ dalam waktu yang sama (6 jam). Setelahnya masing-masing membran ditimbang sehingga didapatkan berat basah membran. Kemudian membran dipanaskan dalam oven dengan suhu $100^{\circ} \mathrm{C}$ selama 24 jam. Setelah 24 jam, membran 
ditimbang kembali sehingga didapat berat kering membran.

Uji fluks, sampel membran diletakan pada alat fluks dan diatur sedemikian rupa sehingga tidak terdapat celah. Akuades dimasukan dalam tabung dalam rangkaian alat tersebut. Tekanan diatur hingga air menetes dan melewati membran. Didapatkan hasil berupa volume air yang menetes pada tekanan dan waktu tertentu pada tiap sampel membran.

\subsubsection{Aplikasi Membran pada Permeasi Urea dan Kreatinin}

Uji permeasi terhadap urea dan kreatinin dilakukan dengan alat permeasi yang terdiri dari dua chamber yaitu chumber sumber dan chumber akseptor yang ditengahnya terdapat membran. Pada fasa sumber berisi urea 500 ppm dan kreatinin 15 ppm yang dibuat dengan 2 jenis buffer yaitu PBS (buffer fosfat salin) dan PB (buffer fosfat), sedangkan fasa akseptor berisi akuades. Permeasi dilakukan selama 6 jam dengan pengamatan tiap jam. Sampel hasil pengamatan akan dikomplekskan sebelum dianalisis menggunakan spektromotometer UV-Vis. Urea dikomplekskan dengan $p$ dimetilaminbenzaldehida yang diukur pada panjang gelombang $430 \mathrm{~nm}$, kreatinin dikomplekskan dengan asam pikrat dianalisis pada panjang gelombang $483 \mathrm{~nm}$ dan permeasi vitamin $B_{12} 25$ ppm yang dianalisis pada panjang gelombang $361 \mathrm{~nm}$.

\section{Hasil dan Pembahasan}

Membran CSTPP berupa lembaran bening tembus cahaya, kuat dan lentur. Memiliki ketebalan dan berat seperti terlihat pada Tabel 1.

Tabe1 1. Hasil pengkuran ketebalan dan berat pada berbagai membran

\begin{tabular}{|c|c|c|}
\hline $\begin{array}{c}\text { Jenis } \\
\text { membran }\end{array}$ & $\begin{array}{c}\text { Berat } \\
\text { (mg) }\end{array}$ & $\begin{array}{c}\text { Tebal } \\
\text { (mm) }\end{array}$ \\
\hline CS & 0,07 & 5,7 \\
\hline CSTPP1 & 0,07 & 7,0 \\
\hline CSTPP2 & 0,08 & 8,3 \\
\hline CSTPP3 & 0,08 & 8,8 \\
\hline
\end{tabular}

\subsection{Karakter Membran CSTPP}

Sintesis membran kitosan tertaut silang tripolifosfat menggunakan metode ionic gelation (ionotropic gelation) pada $\mathrm{pH} 3,8$. Interaksi taut silang terjadi antara muatan negatif dari TPP dan muatan positif gugus amina kitosan. Mekanisme reaksi dapat digambarkan sbb, pada suasana asam terjadi proses protonasi gugus $-\mathrm{NH}_{2}$ (CS) menjadi $-\mathrm{NH}_{3}{ }^{+}$. Selanjutnya muatan negatif TPP akan menyerang muatan positif -NH3, seperti yang ditunjukkan pada Gambar 1 .

Tahap 1 protonasi kitosan

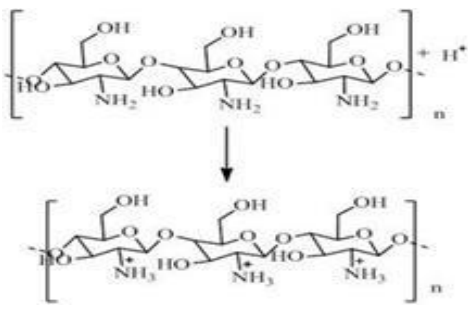

Tahap 2 reaksi taut silang

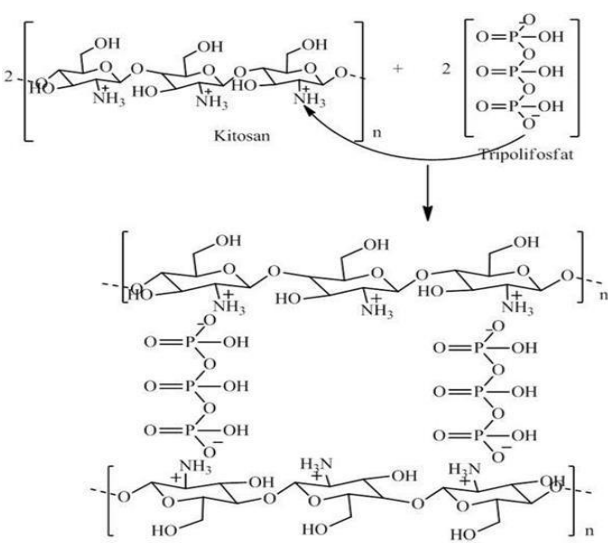

Gambar 1. Mekanisme reaksi taut silang kitosan dengan NaTPP [8]

Keberhasilan reaksi taut silang antara akan dibuktikan dengan spektra FT-IR (Gambar 2). Pada spektra CSTPP menunjukkan vibrasi ikatan C-H pada daerah serapan $2922 \mathrm{~cm}^{-1}$. Terdapatnya serapan pada daerah 1647 dan $1422 \mathrm{~cm}^{-1}$ menunjukkan terbentuknya ikatan baru antara ion amonium dan ion fosfat. Serapan $1156 \mathrm{~cm}^{-1}$ menunjukkan regangan gugus $\mathrm{PO}_{2}$ dalam fosfat. Hasil ini sesuai dengan hasil spectra yang dihasilkan oleh Lusiana dan Protoningtyas [7].

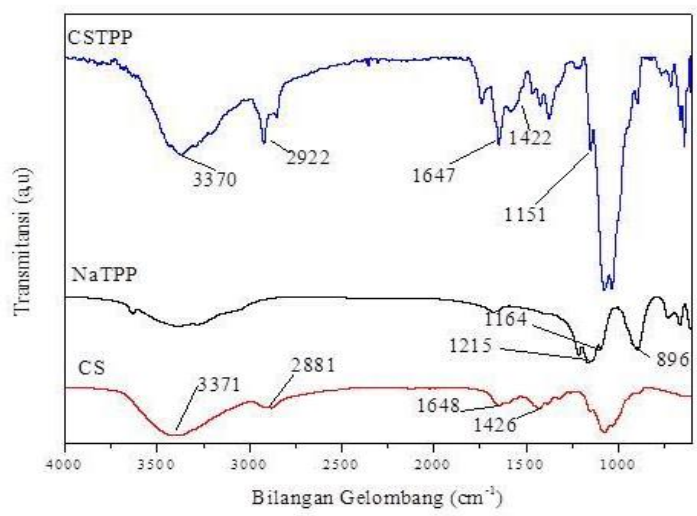

Gambar 2. Spektra FT-IR kitosan (CS), NaTPP murni dan CSTPP

Hasil karakterisasi hiidofilisitas, serapan air, derajat pengembangan, dari membran membran 
CSTPP ditunjukkan pada Tabel 2. Dapat dilihat bahwa TPP meningkatkan hidrofilisitas membran. Meningkatnya TPP yang ditambahkan pada kitosan meningkatkan hidrofilisitas, nilai serapan air dan derajat pengembangan dibandingkan dengan membran kitosan murni. Bertambahnya gugus elektronegatif seperti -O- dari TPP dalam struktur kitosan meningkatkan kemampuan membran untuk berikatan dengan air yang ada di lingkungan membran.

Uji porositas dan fluks membran dapat dilihat pada Gambar 3. Porositas dan fluks air saling berkaitan dimana keduanya mengacu pada besar ruang kosong yang ada pada membran. Meningkatnya konsentrasi TPP yang ditambahkan membuat porositas meningkat sebesar 1,5-2 kali lipat Penambahan TPP tidak serta merta meningkatkan porositas membran, namun pada kasus modifikasi dengan kitosan didapatkan bahwa maksimal TPP yang bisa ditambahkan adalah perbandingan 1:1 dengan mol kitosan. Hal ini dapat diindikasi bahwa pada penambahan TPP ke kitosan terdapat jarak terbaik atau jarak optimal senyawa termodifikasi. Pada proses permeasi dibutuhkan jarak terbaik agar sisi aktif membran dapat secara leluasa berikatan dengan spesi yang akan dipisahkan. Terlihat juga, peningkatan konsentrasi TPP, meningkatkan nilai fluks air. Nilai-nilai tersebut dimungkinkan dengan masuknya TPP ke dalam struktur membran, maka gugus yang mampu berinteraksi dengan air meningkat. Selanjutnya, ketika membran dikeringkan, air yang telah terikat secara ikatan hidrogen dengan gugus fungsi pada struktur membran meninggalkan jejak berupa rongga-rongga kosong serupa pori-pori. Peningkatan porositas membran akan menyebabkan membran memiliki jarak rongga yang cukup dan teratur, sehingga difusi air dengan mudah melewati membran. Secara berurut nilai fluks air membran CS, CSTPP1, CSTPP2, dan CSTPP3 adalah 3,06; 6,73; 116,18 dan $77,05 \mathrm{Lm}^{-2} \mathrm{jam}^{-1}$.

Tabel 2. Hasil uji hidrofilisitas, serapan air, dan derajat pengembangan

\begin{tabular}{cccc}
\hline $\begin{array}{c}\text { Jenis } \\
\text { Membran }\end{array}$ & $\begin{array}{c}\text { Sudut } \\
\text { Kontak } \\
\left({ }^{\circ}\right)\end{array}$ & $\begin{array}{c}\text { Serapan } \\
\text { Air }(\%)\end{array}$ & $\begin{array}{c}\text { Derajat } \\
\text { Pengembangan } \\
(\%)\end{array}$ \\
\hline CS & 80 & 177,2 & 41,7 \\
CSTPP1 & 54 & 199,6 & 21,9 \\
CSTPP2 & 55 & 214,7 & 18,6 \\
CSTPP3 & 63 & 231,2 & 9,0 \\
\hline
\end{tabular}

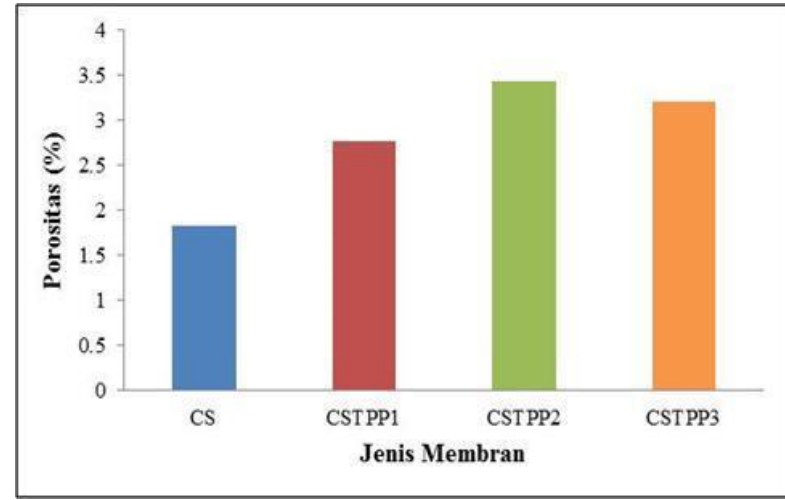

(a)

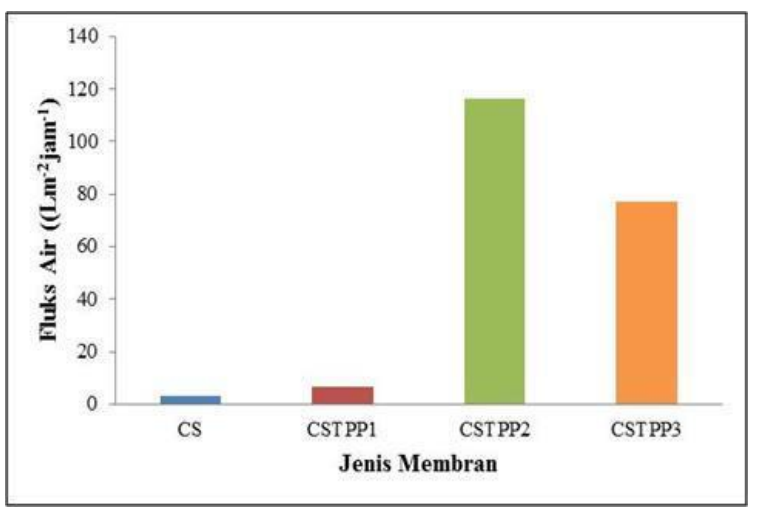

(b)

Gambar 3. Persentase porositas (a) dan fluks terhadap air membran (b)

Selanjutnya dilakukan uji kuat tarik terhadap membran. Uji kuat tarik pada membran dilakukan untuk mengetahui kekuatan dan elastisitas membran apabila diberikan beban tertentu. Pada hasil uji kuat tarik diketahui bahwa jumlah TPP yang ditambahkan mempengaruhi elastisitas membran. Pada membran modifikasi akan menghasilkan membran yang lebih elastis jika dibanding dengan membran kitosan. Hasil uji kuat tarik membran dapat dilihat pada Gambar 4. Berdasarkan hasil uji kekuatan membran dapat disimpulkan bahwa kitosan memiliki tipe membran yang keras dan kuat. Ketika diberi tekanan, membran kitosan cenderung untuk mampu menahan beban tekanan lebih besar dibanding membran kitosan termodifikasi. Membran CSTPP memiliki tipe lunak dan lemah. Artinya membran bersifat lebih elastis dibanding membran kitosan murni. Namun membran lebih mudah robek, ketika dikenai beban tekanan. 


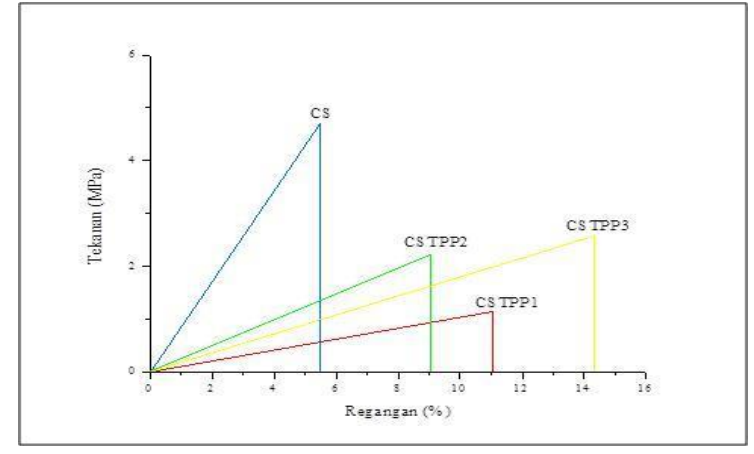

Gambar 4. Hasil uji kuat tarik membran

\subsection{Kemampuan Permeasi Membran}

Pada uji permeasi kreatinin dan urea digunakan dua pelarut untuk melarutkan kedua komponen yaitu larutan buffer fosfat (PB) dan larutan buffer garam fosfat (PBS) sedangkan pada permeasi vitamin B12 menggunakan pelarut akuades. Hasil permeasi kreatinin dan urea dapat dilihat pada Tabel 3.

Tabel 3. Hasil permeasi kreatinin dan urea membran

\begin{tabular}{ccccc}
\hline \multirow{2}{*}{$\begin{array}{c}\text { Jenis } \\
\text { membran }\end{array}$} & \multicolumn{2}{c}{ Permeasi } & \multicolumn{2}{c}{ Permeasi Urea } \\
& Kreatinin (\%) & \multicolumn{2}{c}{$(\%)$} \\
& PBS & PB & PBS & PB \\
\hline CS & 25,25 & 38,12 & 33,16 & 39,46 \\
CSTPP1 & 28.68 & 39,85 & 39,74 & 49,95 \\
CSTPP2 & 37,30 & 44,18 & 45,72 & 55,03 \\
CSTPP3 & 31,74 & 42,74 & 43,86 & 40,42 \\
\hline
\end{tabular}

Berdasarkan pada tabel 3, hasil uji permeasi kreatinin dan urea menunjukkan membran CSTPP2 memiliki kemampuan permeasi paling baik dibanding membran yang lain. Hal ini berkorelasi dengan hasil nilai porositas dan fluks dari membran CSTPP2 yang juga paling tinggi diantara membran yang lain. Hal ini menunjukkan bahwa membran CSTPP2 mempunyai ukuran jejari optimal yang membuat sisi aktif pada membran bergerak leluasa dalam mengikat permeat. Nilai permeasi dalam PBS secara umum memiliki persentase lebih kecil dibanding dalam PB. Keberadaan mineral pada PBS menghalangi gerak molekul permeat untuk mendekat pada permukaan membran.

Tabel 4. Hasil permeasi vitamin $\mathrm{B}_{12}$

\begin{tabular}{ccccc}
\hline \multirow{2}{*}{$\begin{array}{c}\text { Jenis } \\
\text { membran }\end{array}$} & \multicolumn{4}{c}{$\begin{array}{c}\text { Konsentrasi vitamin } \text { B }_{12} \\
\text { (mg/dL) }\end{array}$} \\
& Sumber & \multicolumn{2}{c}{ Akseptor } \\
& $\mathbf{0}$ & $\mathbf{6}$ & $\mathbf{0}$ & $\mathbf{6}$ \\
\hline CS & 2,5 & 2,23 & 0,0 & 0,0 \\
CSTPP1 & 2,5 & 2,22 & 0,0 & 0,0 \\
CSTPP2 & 2,5 & 2,21 & 0,0 & 0,0 \\
CSTPP3 & 2,5 & 2,23 & 0,0 & 0,0 \\
\hline
\end{tabular}

Terkait dengan kemampuan permeasi membran terhadap vitamin B12 diperoleh data pada tabel 4 . Dari tabel 4 didapatkan bahwa keseluruhan membran tidak dapat melewatkan vitamin B12. Dimungkinkan bahwa ukuran partikel vitamin B12 lebih besar dibandingkan dengan pori membran sehingga sulit untuk melewati membran. Hal ini menunjukkan bahwa membran-membran tersebut memungkinkan untuk dapat dimanfaatkan sebagai membran hemodialisis.

\section{Kesimpulan}

Reaksi taut silang kitosan-TPP telah berhasil dilakukan yang dibuktikan dengan spektra FTIR. Penambahan TPP dalam struktur kitosan mempengaruhi sifat fisikokimia membran. NIlai hidrofilisitas, porositas dan fluks membran meningkat dibandingkan dengan membran kitosan murni. Membran CSTPP2 memiliki kemampuan permeasi terhadap kreatinin dan urea yang paling baik diantara membran yang lain.

\section{Daftar Pustaka}

[1] Lusiana, Retno Ariadi, Dwi Siswanta, Mudasir Mudasir, Takashi Hayashita, The Influence of Pva.cl.Citric Acid/Chitosan Membrane Hydrophicility on The Transport of Creatinine And Urea, Indonesian Journal of Chemistry, 13,3,(2013),262-270 https://doi.org/10.22146/ijc.21286

[2] Lusiana, Retno Ariadi, Ginanjar Argo Pambudi, Fitra Nilla Sari, Didik Setiyo Widodo, Khabibi Khabibi, Sri Isdadiyanto, Grafting of Heparin on Blend Membrane of Citric Acid Crosslinked Chitosan/ Polyethylene Glycol-Poly Vinyl Alcohol (PVAPEG), Indonesian Journal of Chemistry,19,1,(2019),151-159 https://doi.org/10.22146/ijc.30861

[3] Nurratri, Alinda Megagita, Khabibi Khabibi, Retno Ariadi Lusiana, Abdul Haris, Rahmad Nuryanto, Pembuatan Dan Karakterisasi Membran Paduan KitosanPolietilenglikol6000, Media Bina Ilmiah, 14, 9,(2020),3261-3270

https://doi.org/10.33758/mbi.v14i9.506

[4] Bhumkar, Devika R., Varsha B. Pokharkar, Studies on Effect of $\mathrm{pH}$ on Cross-Linking of Chitosan with Sodium Tripolyphosphate: A Technical Note, Aaps Pharmscitech, 7, 2, (2006),E138-E143 https://doi.org/10.1208/pt070250

[5] Hejjaji, Ezzeddin M. A., Alan M. Smith, Gordon A. Morris, Designing ChitosanTripolyphosphate Microparticles with Desired Size for Specific Pharmaceutical or Forensic Applications, International journal of 
biological macromolecules, 95, (2017), 564-

573

https://doi.org/10.1016/j.ijbiomac.2016.11 .092

[6] Febriasari, A., D. Siswanta, N. Riyanto, N. Hidayat Aprilita, F. Silvianti, Synthesis, Characterization and Flux Evaluation of Chitosan Tri-Polyphosphate Membrane and Chitosan/Tri-Polyphosphate Membrane Impregnated with Zinc Oxide Nanoparticles, Asian Journal of Chemistry, 30, 11, (2018), 2509-2514

https://doi.org/10.14233/ajchem.2018.214 $\underline{94}$

[7] Lusiana, Retno Ariadi, Wahyu Putri Pranotoningtyas, Membran Kitosan Termodifikasi Tripolifosfat-Heparin dan Aplikasinya Pada Permeasi Urea dan Kreatinin, Analit: Analytical and Environmental Chemistry, 3, 1, (2018), 11-21 http://dx.doi.org/10.23960/aec.v3.i1.2018. p11-21

[8] Hsieh, Feng-Ming, Chih Huang, Tsair-Fuh Lin, Yan-Min Chen, Jui-Che Lin, Study of Sodium Tripolyphosphate-Crosslinked Chitosan Beads Entrapped with Pseudomonas Putida for Phenol Degradation, Process Biochemistry, 43, 1, (2008), 83-92 https://doi.org/10.1016/j.procbio.2007.10. $\underline{016}$ 